\title{
Striped red mullet (Mullus surmuletus, Linnaeus, 1758) in the eastern English Channel and southern North Sea: growth and reproductive biology
}

\author{
K. Mahé*, F. Coppin, S. Vaz, A. Carpentier
}

IFREMER, Centre Manche-mer du Nord, Laboratoire Ressources Halieutiques, Boulogne sur mer, France

*: Corresponding author : Kélig Mahé, email address : kelig.mahe@ifremer.fr

\begin{abstract}
:
Biological information is necessary for population structure assessment of economically important species. There are no known published studies on the age and reproduction of Mullus surmuletus in the north of the Bay of Biscay. The aim of this study was to estimate growth and reproductive biology of this species in the eastern English Channel and southern North Sea from 1089 individuals, observed from February to December 2004. The length-weight relationship was described by the parameters: $a=3.284 .10^{-6}$ and $b=3.243$, being allometrically positive. Ages were determined from increments of otoliths, used entirely after a burning treatment. Marginal-increment analysis showed an annual periodicity of increment formation. Von Bertalanffy growth equations were estimated as $\mathrm{TLt}=51.2\left(1-\mathrm{e}^{-0.19(t+2.904)}\right)$ for females and $\mathrm{TLt}=36.0\left(1-\mathrm{e}^{-0.218(t+3.232)}\right)$ for males. Comparing the observed growth performance index $\left(\varphi^{\prime}=2.676\right)$ from others studies, a positive growth gradient was suggested for $M$. surmuletus from south to north of its distribution area. Females grew significantly faster and reached a larger size at age than males. Length at $50 \%$ maturity was 16.9 and $16.2 \mathrm{~cm}$, respectively, for females and males, corresponding to an estimated age of 1 year for both sexes. In the eastern English Channel, according to both the gonadosomatic indices (GSI) and maturity stages, the observed spawning period of $M$. surmuletus was from May to July. The present description of the red mullet life history characteristics in this region may constitute a preliminary step to future population dynamics modelling and stock assessment exercises.
\end{abstract}




\section{INTRODUCTION}

Striped red mullet occurs along the coast of Europe from the South of Norway (Wheeler, 1978) and the North of the Scotland (Gordon, 1981) to Dakar and in the Mediterranean and Black Seas too. This species has been extensively studied in the Mediterranean Sea and some studies were carried out in the Bay of Biscay (Desbrosses, 1933 and 1935; N’Da, 1992; N'Da and Deniel, 1993), which corresponds to historically important exploitation areas.

Initially considered as a valuable bycatch, the development of striped red mullet exploitation and a strong increase in landings along the eastern English Channel and southern North Sea by French, English and Dutch fleets have been observed since the 1990's. This could be attributed to an expansion of the distribution and local abundance of this species coupled to the decline of traditionally targeted species in these areas and possibly related to the seawater-warming trend (Marchal, 2008; ICES, 2012a). Reports indicated a steady increase in eastern English Channel, present landings reaching ten times recorded landings in 1990 (Marchal, 2008; Carpentier et al., 2009).

Striped red mullet is still a non-quota species in the Northeast Atlantic region and evaluation of the level of stock exploitation has only started 7 years ago (ICES, 2012a). Population dynamics models used for fish stock assessment usually require that the age-length relationship and median age at first reproduction is known. This basic information was lacking in the English Channel and southern North Sea where the species life history traits were likely to be different from the Mediterranean or the Bay of Biscay. Therefore, management may benefit greatly from an increased knowledge of this species biology. 
The aim of the present study was to investigate for the first time, the growth and the reproduction of striped red mullet (Mullus surmuletus) in the eastern English Channel and southern North Sea and verify how they may differ from more southern stocks in the Bay of Biscay and in the Mediterranean.

\section{MATERIALS AND METHODS}

A total of 1089 striped red mullet caught by French trawlers were sampled in the landings made at Boulogne-sur-mer (North of France). This species, caught by the local trawler fleet, is known to originate solely from the eastern English Channel and the southern North Sea. Monthly samples were collected from February 2004 to December 2004 (Table 1). All fresh specimens were examined in the laboratory for Total Length (TL, cm), whole weight (W, g), Gonad Weight (Wg, g), sex and macroscopic maturation stage according to N'Da and Deniel (1993).

In order to estimate the age of each individual, sagittal otoliths were removed from the cranial cavity. As recommended by international expert groups (ICES, 2012b), two techniques were used in order to get the most precise evaluation of the fish age: observation under transmitted light and observation under reflected light before and after burning the whole otolith (Fig. 1).Once prepared, otoliths were immersed in $5 \%$ alcoholic water and layed out under a binocular microscope, connected by a camera to a computer. Then, each sample was analysed using the TNPC software (digital processing of calcified structures, www.tnpc.fr). Finally, each otolith was examined by three different experts in order to limit interpretation error.

To validate the periodicity of increment formation, Marginal Increment (MI) analysis was carried out on otoliths by calculating monthly marginal increment according to the following formula: 
$\mathrm{MI}=\left(\mathrm{R}-\mathrm{r}_{\mathrm{n}}\right) /\left(\mathrm{r}_{\mathrm{n}}-\mathrm{r}_{\mathrm{n}-1}\right)$

Where $\mathrm{R}$ is the otolith radius, $\mathrm{r}_{\mathrm{n}}$ is the distance between the edge and the last growth ring and $r_{n-1}$ is the distance between the edge and the second last growth ring.

Age and total length data were used to describe the striped red mullet growth using the von Bertalanffy model (1938) according to the following formula:

Length growth: $\mathrm{TLt}=\mathrm{TL}_{\infty}\left(1-\mathrm{e}^{-\mathrm{K}(\mathrm{t}-\mathrm{t})} 0_{0}\right)$

Weight growth: $\mathrm{Wt}=\mathrm{W}_{\infty}\left(1-\mathrm{e}^{-\mathrm{K}\left(\mathrm{t}-\mathrm{t}_{0}\right)^{3}}\right)^{3}$ avec $\mathrm{W}_{\infty}=\mathrm{a} \mathrm{TL}_{\infty}^{\mathrm{b}}($ Ricker, 1975)

Where TLt and Wt are the length and the weight at age $t, \mathrm{TL}_{\infty}$ and $\mathrm{W}_{\infty}$ the asymptotic length and weight, $\mathrm{k}$ the rate at which the asymptote is reached and $\mathrm{t}_{0}$ the theoretical age (in years) at zero length (scaling factor). The fish growth was estimated using the growth performance index ( $\left.\varphi^{\prime}\right)$ (Pauly and Munro, 1984): $\varphi^{\prime}=$ $\log \mathrm{K}+2 \log \mathrm{TL}_{\infty}$. Growth performance index was preferred for growth comparison rather than comparison of $\mathrm{L}_{\infty}$ and $\mathrm{K}$ individually, because of the correlation between these two parameters (Sparre et al., 1987).

Sex was determined by macroscopic observation of the gonads. Reproductive maturity stages were assessed macroscopically. According to the criteria proposed by N'Da and Deniel (1993), the maturity development stage of female was assigned as follows: (I) immature; (II) resting; (III) ripe and running; (IV) spent; and (V) post-spent. For males, the maturity development stage II and III were merged. The overall sex ratio and stages of sexual maturity were also determined. Gonads were removed and weighed to the nearest $0.1 \mathrm{~g}$. The spawning period was determined by identifying monthly changes in the gonadosomatic index (GSI). The GSI was calculated using the equation: $\mathrm{GSI}=\mathrm{Wg} / \mathrm{W}$ where $\mathrm{Wg}$ is weight of the fresh gonad, dabbed on absorbing paper. Size and age at first maturity were calculated from $50 \%$ of the fish reaching reproductive maturity (L50). 
Statistical analyses were conducted using the open-source statistical package " $R$ " ( $R$ 2.3.1-A Language Environment(C 2006; The R Development Core Team). Three length/weight relationships on each and both sexes combined were fitted using linear regression after log transformation of the length and of the weight. Analysis of covariance (ANCOVA) was used to assess the differences between the fitted length/weight relationships for males and females . Likelihood Ratio Tests were used to compare the von Bertalanffy growth curves between sexes Kimura (1980). GSI monthly variation was tested using two-way nested ANOVA to detect significant change in the reproductive condition of striped red mullet along the year. Prior to ANOVA analysis, data expressed in percentage were arcsinus square-root transformed. Significant ANOVA was followed by a post hoc multiple comparison test (Newman-Keuls test). Differences were considered significant at $\mathrm{p}<0.05$.

\section{RESULTS}

Out of 1089 M. surmuletus collected from February to December 2004, examined for length, weight, sex, reproductive stages and age, 218 were juveniles, 320 males and 551 were females (Table 1).

\subsection{GROWTH}

Length, weight and length-weight relationship for males, females and both sexes combined are given in Table 2. The length-weight relationship showed a significant positive allometric growth, regardless of the sex of individuals (Table 2). Allometric coefficient of the regression for females was found to be significantly higher than that of males (ANCOVA, $\mathrm{p}=0.032$ ). 
The technique involving burning sagittal otoliths was found to be the most suitable for age determination as it accentuated the visibility of slow growth areas. When viewed with transmitted light after a burning treatment, alternating translucent and opaque bands were clearly visible. The distance between growth rings decreased from the otolith core towards the outer margin. One growth increment consisted of one opaque and one translucent bands, out of which the opaque area was considered to be deposited between June and September. The annual periodicity was confirmed by the marginal increment formation analysis (Fig. 2).

Von Bertalanffy growth parameters for females, males and all fishes were estimated as shown in Table 3. Significant differences in growth parameters were found between sexes (likelihood ratio test: $\chi 2=12.08, \mathrm{df}=3, \mathrm{p}=0.007$ ). Females grew to a greater asymptotic weight $\left(\mathrm{W}_{\infty}\right)$ and length $\left(\mathrm{TL}_{\infty}\right)$ than males (Fig. 3).

\subsection{REPRODUCTIVE BIOLOGY}

First sexual maturity was observed from $15.5 \mathrm{~cm}$ to $18.9 \mathrm{~cm}$ and from $14.7 \mathrm{~cm}$ to $17.1 \mathrm{~cm}$ for females and males respectively, corresponding to fish between 0 and 2 years old. The size at $50 \%$ sexual maturity $\left(\mathrm{TL}_{50}\right)$ was $16.9 \mathrm{~cm}$ and $16.2 \mathrm{~cm}$ for females and males respectively, corresponding to an age close to 1 year old.

Gonad development was followed using the GSI and the frequency of the maturity stages. Monthly changes of GSI were plotted in Figure 4. From May to November, statistically significant differences in GSI were measured (ANOVA, $p<0.05$ ). The highest values of GSI were observed in June. The macroscopic stages from February to December showed the same trend (Fig. 5). Females reproductive activity period (stage IV) was shorter than that of the males, occurring from May to July, with a maximum percentage of mature specimens in June. In contrast, a significant 
proportion of the males were found in capacity to reproduce (stage III, Fig. 5) over all the studied period.

\section{DISCUSSION}

Since the 1990's, M. surmuletus population size strongly increased in the North East Atlantic, in particularly in the eastern English Channel and southern North Sea. For this reason, $M$. surmuletus was included in the list of new species investigated by the International Council for the Exploration of the Sea (ICES) for fish stock assessments feasibility (ICES, 2012a). Population dynamics models are generally based on available age/length keys and median age at first sexual maturity. Thus, it became necessary to investigate the age, growth rate and reproduction maturity of M. surmuletus in the eastern English Channel and southern North Sea from the otoliths.

The validity of our age determination based on counting opaque bands on whole otoliths of $M$. surmuletus were confirmed by the age estimation method analysing marginal increment formation (Renõnes et al., 1995; Pajeulo et al., 1997; N'Da et al., 2006). Therefore, Von Bertalanffy parameters could safely be estimated. Our estimate of asymptotic length (TL $\infty=47.5 \mathrm{~cm})$ was higher than all those reported in other studies (Table 4). However, the observed maximum length found in the present study $(46 \mathrm{~cm})$ was relatively close to that found in the Bay of Biscay (43.5 cm; N'Da, 1992). The lack of large observed individuals (TL $>40 \mathrm{~cm})$ in the Bay of Biscay may explain the large $(10 \mathrm{~cm})$ difference in the asymptotic lengths of English Channel and southern North Sea $(\mathrm{TL} \infty=47.5 \mathrm{~cm})$ and Bay of Biscay $(\mathrm{TL} \infty=37.7 \mathrm{~cm}$; Table 4). Von Bertalanffy parameters indicated that females reached a larger asymptotic total length $\left(\mathrm{TL}_{\infty}\right)$ than males did, but in contrast, the 
growth rate $(\mathrm{K})$ of females was lower than that of males. Growth performance index $\left(\varphi^{\prime}\right)$ of $M$. surmuletus showed the growth of the females was more higher than this of the males (Table 3) This sexual dimorphism was observed in the different areas: Northern Bay of Biscay (N’Da, 1992), Majorca waters (Morales-Nin, 1992; Pajuelo et al., 1997), Egyptian waters (Hashem, 1973), Tirrenian Sea (Andoloro \& Giarritta, 1985) and Tunisian waters (Jabeur, 1999). The growth performance index is considered as a useful tool for comparing growth curves of different populations in a same species (Sparre et al., 1987; Wootton, 1998). In this study this parameter reached 2.676 for combined sexes, which was higher than that observed in the bay of Biscay (2.61, N'Da, 1992) or in the Mediterranean sea, where it ranged between 2.06 and 2.36 (Gharbi and Ktari, 1981; Sanchez et al, 1983; Morales-nin, 1992; Renõnes et al., 1995). In conclusion, a positive growth gradient for M. surmuletus was observed from south to north with a maximum growth performance in the eastern English Channel and in the southern North Sea. Space variability of many organisms' growth rates are known to be a product of environmental conditions, genotype and the potential importance of interactions between these two factors (Conover and Schultz, 1995; Garvey et al., 2003). As a main factor, temperature has a significant effect on growth rates of fish (Taylor, 1958; Uiblein, 2007; Pauly, 2010). Since 1995, striped red mullet abundance increased strongly in the eastern English Channel and southern North Sea (ICES, 2007; Vaz et al., 2007) and was found to be correlated with the temperature augmentation in this area (ICES, 2007). The sea water warming may have facilitated this population increase but the local water temperature range and its seasonal variation are also known to influence the growth rate of the striped red mullet (Uiblein, 2007). Water temperature directly influences the relative oxygen consumption of fish. In colder areas, the metabolic 
rate and oxygen demand is lower and oxygen supply is less likely to limit their growth (Pauly, 2010). However, geographic variability of growth rates cannot be attributed solely to the temperature. In the case of Mullus barbatus, a higher growth rate was observed in the central Mediterranean than that in the south-eastern Mediterranean, which was explained by a reduced primary production and higher temperatures in the south (Sonin et al., 2007). Therefore, other environmental factors such as salinity, food conditions or predation pressure could also control the growth rate of M. surmuletus. Abookire and Macewicz (2003), relating a latitudinal gradient in growth rates of the Dover sole (Microstomus pacificus), suggested that growth was strongly influenced by geographic variations in physical and environmental habitats.

The seasonal pattern of the gonadosomatic index (GSI) and the gonad stages of females suggested the existence of a single synchronous spawning period occurring from May to July in the eastern English Channel and southern North Sea. According to different studies, the reproduction period of $M$. surmuletus may range from February to July and last two to three months (Table 4). It was found to be slightly earlier in the Mediterranean Sea (from February to June) than in the North East Atlantic (from May to July, Table 4), probably due to different ecological and climatic conditions (Nikolsky, 1963). The maturation of gonads may be explained by changes in temperature regime (Wootton, 1998; Lahnsteiner \& Kletzl, 2012). During experimental study using constant day length, Baggerman (1980) showed that the gonadic maturation of the stickleback occurred earlier in warmer temperatures and a similar mechanism probably explains why the reproduction period of $M$. surmuletus is delayed in the northern latitudes. 
For both sexes, the estimated age at sexual maturity was 1 year old as it was in all other available studies (Table 4). As a result, the length at sexual maturity, so important to the management of fishery resources to calculate the Spawning Stock Biomass (SSB) and to define the Minimum Legal Length (MLL), may be extracted directly from the growth models specific to each geographical area and each sex. For both sexes, the growth was important during the first year and slowed down thereafter. This reduction in the growth rate coincided with the age at first maturity reflecting that the energy used for reproduction is no longer available for somatic growth (Pauly, 2010). Estimated length at sexual maturity was slightly higher for females $(16.9 \mathrm{~cm})$ than for males $(16.2 \mathrm{~cm})$ (Table 4). Males were found capable of spawning all year long (stage III, Fig. 4) and seemed to allocate energy to their gonadic growth earlier than females probable explaining their slightly smaller growth rate. These observed values were amongst the highest and were found to be similar only to those of the Canary Islands (Pajeulo et al., 1997). The later reproductive maturation of red mullet in the eastern English Channel may favour its growth and explain the observed differences.

In conclusion, our results seemed to indicate that $M$. surmuletus has acclimatized to the eastern English Channel and southern North Sea exhibiting an increased growth rate and delayed reproduction period than in more southern areas. In 2012, it was decided to separate M. surmuletus population in two stocks. The eastern English Channel and southern North Sea now compose the north stock and the western English Channel, the Celtic Sea and the Bay of Biscay compose the south stock (ICES, 2012a). In 2013, the results of this study will be integrated in the first north stock assessment of the striped red mullet. The biological monitoring of this species 
life history traits will become necessary to a scientifically sound fishery management.

\section{ACKNOWLEDGEMENTS}

This study was carried out with the financial support of the European fisheries fund (EFF), the Nord-Pas-de-Calais region, the regional council of Picardie and the regional committee of fisheries (CRPMEM) of Nord-Pas-de-Calais. We are grateful to Adeline Destombes, Didier Le Roy and staff who participated to samplings for their contribution to this study.

\section{REFERENCES}

Abookire, A. A., Macewicz, B. J., 2003: Latitudinal variation in reproductive biology and growth of female Dover sole (Microstomus pacificus) in the North Pacific, with emphasis on the Gulf of Alaska stock. J. Sea Res. 50(2-3), 187-197.

Andaloro, F., Giarritta, S. P., 1985: Contribution to the knowledge of the age and growth of striped mullet, Mullus barbatus (L. 1758) and red mullet, Mullus surmuletus (L. 1758) in the Sicilian Channel. GFCM. Report Of The Second Technical Consultation On Stock Assessment In The Central Mediterranean, Mazara Del Vallo, Italy, 336, pp.89-92.

Baggerman, B., 1980: Photoperiodic and endogenous control of reproduction in teleost fishes. In: Environmental physiology of fishes. M. A. Ali (Eds), Plenum Publishing Corp. New York. pp 537-567.

Beare, D. J., Burns, F., Peach, K., Reid, D. G., 2005: Red mullet migration into the northern North Sea during late winter. J. Sea Res. 53, 205-212. 
von Bertalanffy, L., 1938: A quantitative theory of organic growth. Hum. Biol. 10(2), 181-213.

Carpentier, A., Martin, C. S., Vaz, S., 2009. Channel Habitat Atlas for marine Resource Management (CHARM phase II), INTERREG 3a Programme, IFREMER, Boulogne-sur-mer.

Conover, D. O., Schultz, E. T., 1995: Phenotypic similarity and the evolutionary significance of counter gradient variation. Trends Ecol. Evol. 10, 248-252.

Desbrosses, P., 1933: Contribution a la biologie du rouget-barbet en Atlantique Nord. Rev. Trav. Off. Pêches marit. 6(3), 249-270.

Desbrosses, P., 1935: Contribution a la connaissance de la biologie du rouget barbet en Atlantique Nord . Mullus barbatus (rond) surmuletus (Fage). Mode septentrional Fage. Rev. Trav. Off. Pêch. marit. 8(4), 351-376.

Garvey, J. E., Devries, D. R., Wright, R. A., Miner, J. G., 2003: Energetic adaptations along a broad latitudinal gradient: implications for widely distributed assemblages. Bioscience 53, 141-150.

Gharbi, H., Ktari, M. H., 1981: Croissance des rougets en Tunisie. Bull. Inst. Oceanogr. Pêche Salammbô 8, 5-40.

Gordon, J. D. M., 1981: The fish populations of the west of Scotland shelf. Part II. Oceanogr. Mar. Biol. Annu. Rev. 19, 405-441.

Hashem M. T., 1973: Age growth and maturity of the goat fish (Mullus barbatus L.) in Abukir-Rosetta region during 1969-1970. Bull. Inst. Oceanogr. Fish. Cairo 3, $163-182$

ICES. 2007: Report of the Working Group on Fish Ecology (WGFE), 5-9 March 2007, Nantes, France. ICES CM 2007/LRC: 03. 217 p. 
ICES. 2012a: Report of the Working Group on Assessment of New MoU Species (WGNEW), 5 - 9 March 2012, Copenhagen, Denmark. ICES CM 2012/ACOM: 20. $258 \mathrm{p}$

ICES. 2012b. Report of the workshop on age reading of red mullet and striped red mullet (WKACM2), 2 - 6 July 2012, Boulogne-sur-Mer, France. ICES CM 2012/ACOM: 60. 52 p.

Jabeur, C., 1999: La pêche dans le Golfe de Gabès : interactions techniques entre les métiers et exploitation partagée du rouget rouge (Mullus surmuletus L., 1758). PhD Thesis. Univ. de Bretagne Occidentale, Brest, France, 164 p.

Kimura, D. K., 1980: Likelihood methods for the von Bertalanffy growth curve. U. S. Fish. Bull. 77(4), 765-776.

Lahnsteiner, F., Kletzl, M., 2012: The effect of water temperature on gamete maturation and gamete quality in the European grayling (Thymalus thymallus) based on experimental data and on data from wild populations. Fish Physiol. Biochem. 38, $455-467$

Marchal, P. 2008. A comparative analysis of métiers and catch profiles for some French demersal and pelagic fleets. ICES J. Mar. Sci. 65, 674-686.

Morales-Nin, B., 1992: Biological parameters of red mullet Mullus surmuletus L. 1758 off Majorca (in Spanish). Bol. Inst. Esp. Oceanogr. 7(2), 139-147.

N'Da, K., 1992: Biologie du rouget de roche Mullus surmuletus (Poisson Mullidae) dans le Nord du golfe de Gascogne : reproducteurs, larves et juveniles. PhD Thesis. Univ. de Bretagne Occidentale, Brest, France, 177 p.

N'Da, K., Deniel, C., 1993: Sexual cycle and seasonal changes in the ovary of the red mullet, Mullus surmuletus, from the southern coast of Brittany. J. Fish Biol. 43(2), 229-244. 
N'Da, K., Deniel, C., Yao, K., 2006. Croissance du rouget de roche Mullus surmuletus dans le nord du golfe de Gascogne. Cybium 30(1), 57-63.

Nikolsky, G. V., 1963: The ecology of fishes, Academic Press (Eds). London, 352 p.

Pajuelo, J. G., Lorenzo, J. M., Ramos, A. G., Villamil-Mata, M., 1997: Biology of the red mullet Mullus surmuletus (Mullidae) off the Canary Islands, central east Atlantic. S. Afr. J. mar. Sci. 18, 265-272.

Pauly, D., Munro, J. L., 1984: Once more on the comparison of growth in fish and invertebrates. Int. Cent. Living Aquat. Resour. Manage. Fishbyte 2, 21 p.

Pauly, D., 2010: Gasping fish and panting squids: oxygen, temperature and the growth of water-breathing animals. Kinne, O., (Eds). Excellence in ecology. Book 22. International Ecology Institute, Oldendorf/Luhe.

Renones, O., Massuti, E., Morales-Nin, B., 1995: Life history of the red mullet Mullus surmuletus from the bottom-trawl fishery off the Island of Majorca (northwest Mediterranean). Mar. Ecol. Prog. Ser. 123, 411-419.

Ricker, W. E., 1975: Computation and interpretation of the biological statistics of fish populations. B. Fish. Res. Board Can. 191, 1-382.

Robinson, J. M., Jirka, K. J., Chiotti, J. A., 2010: Age and growth analysis of the central mudminnow, Umbra limi (Kirtland, 1840). J. Appl. Ichthyol. 26, 89-94.

Sanchez, P., Morales-Nin, B., Martin, P., 1983: The mullets (Mullus surmuletus L., 1758, Mullus barbatus L., 1758) of the Catalan coast: biological and fishing aspects. Int. Counc. Explor. Sea. Comm. Meet. (Demersal Fish Comm.) G, 27, 1-19. Sonin, O., Spanier, E., Levi, D., Patti, B., Rizz, P., Andreoli, M. G., 2007: Nanism (dwarfism) in fish: a comparison between red mullet Mullus barbatus from the southeastern and the central Mediterranean, Mar. Ecol-Prog. Ser. 343, 221-228. 
Sparre, P., Ursin, E., Venema, S. C., 1987: Introduction to tropical fish stock assessment. Part 1: manual. FAO Fisheries Technical Paper, Roma, Italy, 376 p.

Taylor, C. C., 1958: Cod growth and temperature. J. Cons. Int. Explor. Mer. 23, 366-370.

Uiblein, F., 2007: Goatfishes (Mullidae) as indicators in tropical and temperate coastal habitat monitoring and management. Mar. Biol. Res. 3, 265-288.

Vaz, S., Carpentier, A., and Coppin, F. 2007. Eastern English Channel fish assemblages: measuring the structuring effect of habitats on distinct subcommunities. ICES J. Mar. Sci. 64, 271-287.

Wheeler, A., 1978: Key to the fishes of the British Isles and northern Europe: a guide to the identification of more than 350 species. F. Warne Ltd (Eds). London.

Wootton, R. J., 1998: Ecology of teleost fishes. Kluwer Academic Publishers (Eds). London, 386 p. 
Figure 1: Striped red mullet whole otoliths before and after burning (transmitted light).

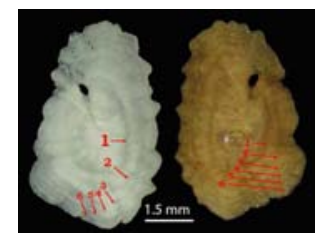

Figure 2: Monthly trend of average marginal increment $\left(\mathrm{mm} . \mathrm{month}^{-1}\right.$; mean $\left.\pm \mathrm{SD}\right)$ on the sagittal otolith of the Striped red mullet in the eastern English Channel and southern North Sea $(n=128)$.



Figure 3 : The von Bertalanffy growth curves of the Striped red mullet in the eastern English Channel and southern North Sea for females (dashed line) and males (solid line) fitted to the data $(n=383)$.

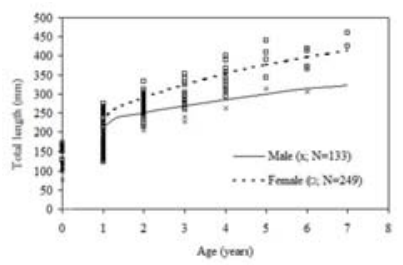

Figure 4: Box and whisker plots of monthly gonadosomatic indices (GSI). Boxes represented $50 \%$ of the population between Q1 and Q3 around the median. Whiskers showed the minimum and the maximum values excluding outliers. Letters indicated statistical differences between months. Those not sharing a common letter 
were significantly different $(\mathrm{p}<0.05)$. For each month, sample size, n, was also indicated.

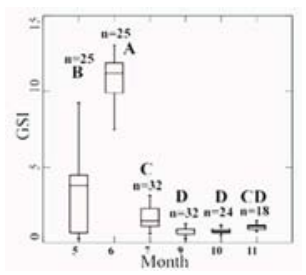

Figure 5 : Frequency of the maturity stages by month and sex (A: Female, B: Male) of Mullus surmuletus sampled in the eastern English Channel and southern North Sea. Females and males numbers by month are presented in Table 1.

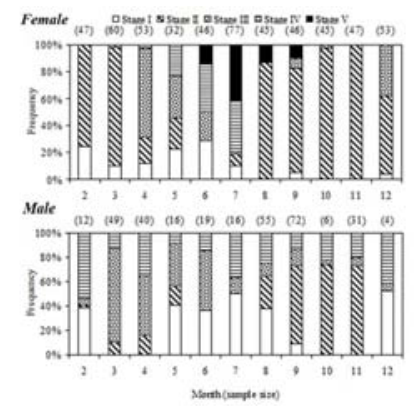

Table 1: Numbers of individuals of Mullus surmuletus observed by month and sex.

\begin{tabular}{|c|c|c|c|c|}
\hline Month & Females & Immature & Males & Total \\
\hline 2 & 47 & 1 & 12 & 60 \\
\hline 3 & 60 & 1 & 49 & 110 \\
\hline 4 & 53 & 5 & 40 & 98 \\
\hline 5 & 32 & 5 & 16 & 53 \\
\hline 6 & 46 & 60 & 19 & 125 \\
\hline 7 & 77 & 0 & 16 & 93 \\
\hline 8 & 45 & 5 & 55 & 105 \\
\hline 9 & 46 & 2 & 72 & 120 \\
\hline 10 & 45 & 50 & 6 & 101 \\
\hline 11 & 47 & 0 & 31 & 78 \\
\hline 12 & 53 & 89 & 4 & 146 \\
\hline Total & 551 & 218 & 320 & 1089 \\
\hline
\end{tabular}

Table 2 : Total Length-weight relationships $\left(\mathrm{W}=\mathrm{a} . \mathrm{TL}^{\mathrm{b}}\right)$ for female, male and both sexes combined of Mullus surmuletus sampled in the eastern English Channel and southern North Sea. Coefficient of determination $\left(\mathrm{r}^{2}\right)$ and significance level (p- 
value) of the fitted relationships after log transformation of the length and of the weight.

\begin{tabular}{|c|c|c|c|c|c|c|c|}
\hline Sex & $\mathrm{n}$ & $\begin{array}{c}\mathrm{TL}(\mathrm{mm}) \\
\text { mean } \pm \text { SD } \\
(\min -\mathrm{max})\end{array}$ & $\begin{array}{c}\mathrm{W}(\mathrm{g}) \\
\operatorname{mean} \pm \mathrm{SD} \\
(\min -\max )\end{array}$ & $\mathrm{a}$ & $\mathrm{b}$ & $\mathrm{r}^{2}$ & p-value \\
\hline Female & 736 & $\begin{array}{c}240.41 \pm 53.47 \\
(114-425)\end{array}$ & $\begin{array}{l}205.62 \pm 138 \\
04(14-1055)\end{array}$ & $3,178.10^{-6}$ & 3,252 & 0,952 & 0,000 \\
\hline Male & 353 & $\begin{array}{c}200.99 \pm 38.78 \\
(77-326)\end{array}$ & $\begin{array}{c}111.44 \pm 66.2 \\
3(7-453)\end{array}$ & $4,821.10^{-6}$ & 3,177 & 0,976 & 0,000 \\
\hline $\begin{array}{l}\text { Both sexes } \\
\text { combined }\end{array}$ & 1089 & $\begin{array}{c}215.65 \pm 62.42 \\
(77-425)\end{array}$ & $\begin{array}{c}141.21 \pm 136 \\
67(7-1055)\end{array}$ & $3,284.10^{-6}$ & 3,243 & 0,973 & 0,000 \\
\hline
\end{tabular}

Table 3 : Von Bertalanffy Growth parameters and performance indices ( $\left.\varphi^{\prime}\right)$ for each sex of Mullus surmuletus sampled in the eastern English Channel and southern North Sea.

$\begin{array}{ccccccc}\text { Sex } & \mathrm{n} & \mathrm{L}_{\infty}(\mathrm{cm}) & \mathrm{W}_{\infty}(\mathrm{g}) & \mathrm{K} & \mathrm{T}_{0} & \varphi^{\prime} \\ \text { Female } & 551 & 51,17 & 1895,24 & 0,196 & -2,904 & 2,710 \\ \text { Male } & 320 & 36,04 & 486,54 & 0,218 & -3,232 & 2,452\end{array}$

Table 4 : Growth ( $\left.\mathrm{TL}_{\infty}, \mathrm{K}, \varphi^{\prime}\right)$ and sexual ( $\mathrm{TL}_{50}$ and spawning seasons) parameters for Mullus surmuletus in different geographical areas.

\begin{tabular}{|c|c|c|c|c|c|c|c|c|c|c|}
\hline Area of study & $\mathrm{n}$ & $\begin{array}{c}\text { Length } \\
\text { range }(\mathrm{cm})\end{array}$ & $\begin{array}{c}\text { Age } \\
\text { Classes }\end{array}$ & $\begin{array}{c}\text { Calcified } \\
\text { piece }\end{array}$ & $\begin{array}{c}\mathrm{TL}_{\infty} \\
(\mathrm{cm})\end{array}$ & $\mathrm{K}$ & $\varphi$, & $\begin{array}{c}\mathrm{TL}_{50}(\mathrm{~cm}) \\
(\mathrm{F}: \text { female, M: } \\
\text { male })\end{array}$ & $\begin{array}{c}\text { Spawning } \\
\text { seasons }\end{array}$ & Citation \\
\hline $\begin{array}{c}\text { Eastern } \\
\text { English } \\
\text { Channel- } \\
\text { southern } \\
\text { North Sea }\end{array}$ & 383 & $7,7-46$ & $0-7$ & Otolith & 47,50 & 0,21 & 2,67 & $\mathrm{~F}: 16,9$ & $5-7$ & $\begin{array}{c}\text { M: } 16,2 \\
\text { present } \\
\text { study }\end{array}$ \\
\hline $\begin{array}{c}\text { Bay of Biscay } \\
\text { Canary }\end{array}$ & 493 & $16,6-43,5$ & $2-9$ & Otolith & 37,73 & 0,29 & 2,61 & $\mathrm{~F}+\mathrm{M}: 15,5$ & $5-6$ & N'Da, 1992 \\
\hline $\begin{array}{c}\text { Islands } \\
\text { Majorca } \\
\text { waters }\end{array}$ & 723 & $11-29$ & $1-8$ & Otolith & 29,8 & 0,24 & 2,32 & $\begin{array}{c}\mathrm{F}: 16,9 \\
\mathrm{M}: 16,3\end{array}$ & $2-5$ & $\begin{array}{c}\text { Pajeulo } \text { et } \\
\text { al., } 1997\end{array}$ \\
\hline $\begin{array}{c}\text { Majorca } \\
\text { waters }\end{array}$ & 1215 & $12-33$ & $0-6$ & Otolith & 31,30 & 0,21 & 2,31 & $\begin{array}{c}\mathrm{F}: 16,8 \\
\mathrm{M}: 15\end{array}$ & $3-6$ & $\begin{array}{c}\text { Renonnes } \text { et } \\
\text { al., } 1995\end{array}$ \\
\hline $\begin{array}{c}\text { Catalonia } \\
\text { waters }\end{array}$ & 3339 & $12-32$ & $0-6$ & Otolith & 32,52 & 0,11 & 2,06 & - & - & $\begin{array}{c}\text { Sanchez } \text { et } \\
\text { al., } 1983\end{array}$ \\
\hline Tunisia waters & 202 & $8-23$ & $0-5$ & Scale & 21,51 & 0,50 & 2,36 & $\begin{array}{c}\mathrm{F}: 15,5 \\
\text { M: } 13\end{array}$ & $4-5$ & $\begin{array}{c}\text { Gharbi \& } \\
\text { Ktari, } 1981\end{array}$ \\
\hline
\end{tabular}




\begin{tabular}{|c|c|c|c|c|c|c|c|c|c|c|} 
Tunisia waters & 123 & $5-23$ & $0-6$ & Otolith & 22,30 & 0,34 & 2,23 & - & - & $\begin{array}{c}\text { Jabeur } \text { et al. }, \\
2000\end{array}$ \\
\hline
\end{tabular}

